\title{
Explaining the Relationship between Organizational Climate, Organizational Commitment, Job Involvement and Organizational Citizenship Behavior among Employees of Khuzestan Gas Company
}

\author{
Farhad Gheisari \\ Department of management, Ramhormoz Branch, Islamic Azad University, Ramhormoz, Iran. \\ Email: Farhad Gheisari (f_shab2007@yahoo.com)
}

\begin{abstract}
Ayyub Sheikhy
Assistant Professor Departments of Statistics, Faculty of Mathematics and Computer, Shahid Bahonar University of Kerman.
\end{abstract}

Rostam Derakhshan

Department of management, Ramhormoz Branch, Islamic Azad University, Ramhormoz, Iran.

\section{Doi:10.5901/mjss.2014.v5n20p2986}

\begin{abstract}
The purpose of this study is to explain the relationship between variables of organizational climate, organizational commitment, job involvement and organizational citizenship behavior. The study population included 1276 employees of the gas company in Khuzestan province, and 296 subjects were selected according to Cochran formula. To collect data, questionnaires of OCB Podsakoff et al (1990), organizational commitment of Allen and Meyer (2010), job involvement of Edward Zuchil Patrick (1984) and the organizational climate of Halpin and Craft were used. To analyze the data, Lisrel 8.80 and spss16 were used and results of structural equations and Pearson correlation coefficients indicated that there is significant relationship between organizational climate and organizational commitment, between organizational commitment and job involvement, between job involvement and organizational citizenship behavior, between organizational citizenship behavior and organizational climate and job involvement.
\end{abstract}

Keywords: Organizational climate, Organizational commitment, Job involvement and Organizational citizenship behavior

\section{Introduction}

People in the organizations have various attitudes that affect their behavior in the organization, among them job involvement is the newest one to enter organizational behavior. Owens considers job involvement as the degree or the extent, to which a person is cognitively engaged in his profession, represents him by it, he is interested in it and it brought honor and prestige to him (Owens, 1986). In fact, in the job involvement, job represents a person and he does his job in terms of components such as respect, loyalty and acceptance of conformity and willingness to exert effort to achieve goals and in other words the individual actually spends his time with his job (Abbasi, 1998). But occupational commitment helps individuals to identify themselves with the organization and its goals and wishes to be a member of the organization (Miller, 2003). On the other hand, Gonzalo et al (2006) have considered the job commitment and job involvement associated with organizational factors, especially organizational climate. In other words, employees who have a healthy working environment can progress by applying all their power, in order to have greater efficiency and a better working environment (Gonzalez \& grazzo, 2006). Brown and Moberge believe that organizational climate is a collection of cultures, customs and practical special methods that has been viewed by organizational members that: (1) describes the organization, (2) separates organization from other organizations and institutions, (3) is relatively stable over time, and (4) people are affected and guided by it. On the other hand the organizational climate is affected on employees' willingness to do things beyond their roles in the organization so that both the individual and the organization benefit from this practice.

The present study attempts to examine the relationship between organizational commitment and organizational citizenship behavior and the role of the intermediary variables of organizational climate and job involvement are 
considered too.

\section{Research Literature}

\subsection{Organizational commitment}

Organizational commitment is one of the job attitudes that affect important behaviors such as turnover and absenteeism (Robbins, 2010). In Steeres' opinion commitment can be caused by personal factors such as age and years of service or by the organizational features such as the freedom of employees in decision making and job security (Soleimani \& Haghiri, 2011). Organizational commitment is real power to individuals consider themselves committed to the organizations and the organization representing them (Arnold, 2005) and it helps individuals to understand their identity in accordance with the organization and its goals and wishes to be a member of the organization (Miller, 2003).

According to Meyer and Allen commitment can be classified in three dimensions:

1- Affective commitment: it arises in situations where because of the emotional attachment a person is willing to continue its work in the organization.

2- Continuance commitment: according to this component, because the person needs the salary and benefits of the organization, s/he continues to work in the organization.

3- Normative commitment: this commitment originates from the values of the person who works in the organization, that is the person believes that he owes his workplace (Meyer and Allen, 1991).

Soleimani and Haghiri (2011) suggest that Porter and et al consider organizational commitment including three factors:

1- Believing in the organization's goals and values 2- tendency to more efforts in the organization 3.tendency to try to stay in organization

\subsection{Organizational citizenship Behavior}

The term OCB for the first time was used in 1983 by Organ and his colleagues although people like Katz and Kahn considered it before them by applying the distinction between the role performance and innovative and spontaneous behaviors in the seventies and eighties $A D$ and before them Chester Barnard considered it by explaining tendency to cooperation in 1938. (Podsakoff, $p$ et al, 2000) believes organizational citizenship behavior is a behavior that is voluntary and has not been designed directly by the formal reward systems in organizations, but despite it improves the effectiveness and efficiency of organizational performance (Appelbaum, 2004). The proposed definition shows that OCB should be a voluntarily behavior not a predetermined duty and not a part of the official duties of the person and it is a behavior that is not rewarded directly or through formal organizational structure is not appreciated. A behavior beyond what is formally is organized for personnel that are important to the success of the organization and organizational performance (Senobari, 2008).

\subsection{Organizational citizenship Behavior dimensions}

The results of the literature suggest that different dimensions have been expressed for organizational citizenship and a number of them are mentioned in the table below. 
Table 1. Dimensions of organizational citizenship Behavior

\begin{tabular}{|c|c|c|c|}
\hline row & OCB dimensions & presenter & reference \\
\hline 1 & $\begin{array}{l}\text { 1.relief Behavior 2.Chivalry 3.Organizational commitment 4.Organizational } \\
\text { obedience 5.Individual initiative 6.Civic virtue 7.Self Improvement }\end{array}$ & $\begin{array}{l}\text { Podsakoff, p. et al., } \\
2000\end{array}$ & $\begin{array}{l}\text { Podsakoff, p. et } \\
\text { al., } 2000\end{array}$ \\
\hline 2 & $\begin{array}{l}\text { 1.Relief Behavior 2.Chivalry 3.Individual initiative 4.social costume 5.Organizational } \\
\text { commitment 6.Self satisfaction 7.Personal development }\end{array}$ & Podsakoff,2000 & Castro et al,2004 \\
\hline 3 & 1.Chivalry 2.Social costume 3.Altruism 4.Consciousness & Netemeyer,1997 & Castro et al,2004 \\
\hline 4 & $\begin{array}{l}\text { 1.Effective and active assistance 2.Avoiding behavior that may hurt partners, } \\
\text { organizations and individuals }\end{array}$ & \begin{tabular}{|l|} 
Livia \\
Markoczy,2004 \\
\end{tabular} & Vigoda,2000 \\
\hline 5 & $\begin{array}{l}\text { 1.Persisting with enthusiasm and extra effort 2.Volunteering } 3 \text {.help to perform work } \\
\text { activities and working with others } 4 \text {.supporting institutional rules and practices } \\
\text { 5.supporting and defending organizational objectives }\end{array}$ & Borman et al,2001 & Borman et al,2001 \\
\hline 6 & $\begin{array}{l}\text { 1.Social manner 2.Consciousness 3.Altruism 4.Work harmony 5.Supporting } \\
\text { organizational resources }\end{array}$ & Fareh et al,1997 & Markoczy,2004 \\
\hline 7 & 1. Social manner 2. Consciousness 3.Altruism 4.Chivalry 5.Courtesy & Organ,1983 & $\begin{array}{l}\text { Markoczy \& } \\
\text { Xin,2004 }\end{array}$ \\
\hline
\end{tabular}

\subsection{Organizational climate}

The organizational climate just like the other definitions of management fields has different definitions. Some have considered it the same as the environment (Farmihani Farahani, 1999). Organizational climate refers to the set of elements that are outside the scope of an organization but in general these elements are affective in an organization's activities (Kadivar, 1996). Alagheband (2004) considers organizational climate as all internal and external factors that surround an organization.

\subsection{Types of organizational climate}

In 60s and Halpin and Craft have done a study in relation to organizational climate and identified six types of organizational climates:

Open climate: In this climate teachers (staff) have a high spirit and they work well together without aggression and conflict. This climate facilitates management strategies, tasks and $f$ affairs and people are not disruptive to each other and the teachers enjoy friendship.

Autonomous climate: Teachers are fairly free in the so that they can find a way to satisfy their social needs. Teachers (staff) are busy with their work and can quickly and easily achieve their goals.

The controlled Climate: controlled climate becomes clear with pressure to achieve organization goals at the expense of satisfying social needs. All work hard and have little time to have friendly relationship with each other and it emphasizes on doing tasks.

Friendly climate: in this climate the manager believes that all members are a family. He avoids doing things that hurt the feelings of its members.

Paternal climate: teachers do not work together well and this is causing a lack of coordination among them. Teachers are not friendly and morale is down markedly among them. The manager controls teachers everywhere.

The closed climate: In this climate the teachers do not involved themselves in the affairs of the organization. Teachers'(employees) job satisfaction is at a low level. The teachers try to satisfy themselves through communicate with each other through their private relations. Most teachers are interested in the job release (Mirkamali, 2001).

\section{Job Involvement}

Job involvement can be defined as the involvement of people in their work. Persons, who are engaged in their work, are known and motivated by it. They tend to work harder and more efficient than others and it is more probable for them to achieve results that customers and the organization seek. Employees with job involvement means that they are good at using their job skills and their abilities, their jobs are challenges and they are considered personal achievement for employees (Roux, 2010).

Job involvement becomes more complete when employees have positive feelings towards their jobs, they find their 
work meaningful, they consider its capacity to control and operate, and they are hopeful about their job future (MirMohammadi, 2012). Triggers of job involvement include job resources, superior job resources, and personal resources. Job resources such as social support from colleagues and superiors, a variety of skills, independence in work and educational opportunities are positively correlated with job involvement. Superior career resources, according to the theory of conservation of resources, people seek the things that are valuable to them. Personal resources are positive self-assessment related to the people to understand their ability to control and influence of their environment (Bakker \& Demerouti, 2008)

Employees with high job involvement are more pleasant with their jobs and dropout rates and absenteeism are lower among them (Mahdad, 2008). Job involvement is related to personal characteristics and the nature of the work tasks and it increases social factors such as teamwork, participation in decision-making, the extent to which employees support the organization's goals and it promotes a sense of accomplishment and progress in jobs and the level of job involvement (Zare Bahram Abadi et al, 2010).

Based on the research literature and the above-mentioned materials, the research conceptual model of this study is as follows:

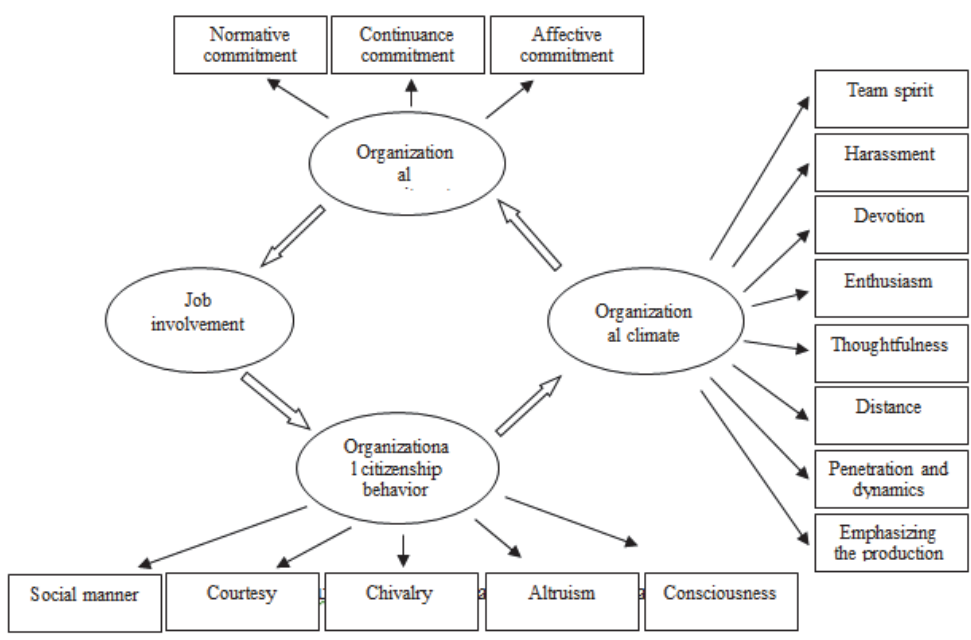

Figure 1. Conceptual model of research

\section{The Research Hypotheses}

1. There is a significant relationship between organizational climate and organizational commitment.

2. There is a significant relationship between organizational commitment and job involvement.

3. There is a significant relationship between job involvement and organizational citizenship behavior.

4. There is a significant relationship between organizational citizenship behavior and organizational climate.

5. There is a significant relationship between organizational climate and job involvement.

\section{Research Method}

In terms of research implementation, this study is a descriptive - correlation study. Because this study assesses the current situation, and describe the current state, studies the properties and it has studied the relationship between the variables. This research is a correlation matrix or a covariance analysis in which structural equation modeling was used.

The population consisted of 1276 employees of the gas company in Khuzestan which 296 samples were selected on the basis of Cochran formula. To collect data, questionnaires of OCB Podsakoff et al (1990), organizational commitment of Allen and Meyer (2010), job involvement Edwards Zookil Patrick (1984) and the organizational climate of Halpyn and Craft were used. The questionnaires were scored according to the Likert scale except job involvement questionnaire in which the grading is based on a scale of 4 degrees that is in positive questions $(1,2,3,4,5,6,7,8,9$, 
$12,15,20)$ grade $3,2,1,0$ are given to completely disagree, disagree, agree and strongly agree, respectively, and negative questions $(10,11,13,14,16,17,18,19)$ are in reverse order, that is scores of $0,1,2,3$ are given to the choices completely disagree, disagree, agree, strongly agree, respectively. To data inferential analysis Lisrel software and in inferential statistics, structural equation modeling method was used.

Table 2. Characteristics of the study questionnaire

\begin{tabular}{|l|l|l|l|l|}
\hline Questionnaire & Organizational climate & $\begin{array}{l}\text { Organizational } \\
\text { commitment }\end{array}$ & Job Involvement & $\begin{array}{l}\text { Organizational } \\
\text { citizenship behavior }\end{array}$ \\
\hline dimensions & $\begin{array}{l}\text { Team spirit, Harassment, Devotion, } \\
\text { Enthusiasm, Thoughtfulness, distance, } \\
\text { Penetration and dynamics, Emphasizing } \\
\text { the production }\end{array}$ & $\begin{array}{l}\text { Affective commitment, } \\
\text { Continuance commitment, } \\
\text { Normative commitment }\end{array}$ & $\begin{array}{l}\text { Altruism, conscientious, } \\
\text { Chivalry, courtesy, } \\
\text { social manners }\end{array}$ \\
\hline $\begin{array}{l}\text { Cronbach's } \\
\text { alpha coefficient }\end{array}$ & $\% 89$ & $\% 77$ & $\% 87$ & $\% 88$ \\
\hline Ranking Options & Very low, low, medium, high, very high & $\begin{array}{l}\text { Highly disagree, slightly } \\
\text { disagree, no idea, slightly } \\
\text { agree, highly agree }\end{array}$ & $\begin{array}{l}\text { Totally disagree, } \\
\text { disagree, agree, } \\
\text { strongly agree }\end{array}$ & $\begin{array}{l}\text { Very low, low, medium, } \\
\text { high, very high }\end{array}$ \\
\hline
\end{tabular}

\section{Data Analysis}

Before examining the hypotheses, it is necessary to consider the correlation between latent variables. Table 3 shows the results of analyzing the relationship correlation between the number of latent variables related directly and significantly $(P$ $<0.05)$ with each other.

Table 3. Correlations between study variables

\begin{tabular}{|l|c|c|c|c|}
\hline Variable & $\begin{array}{c}\text { Organizational } \\
\text { climate }\end{array}$ & $\begin{array}{c}\text { Organizational } \\
\text { commitment }\end{array}$ & $\begin{array}{c}\text { Job } \\
\text { involvement }\end{array}$ & $\begin{array}{c}\text { Organizational citizenship } \\
\text { behavior }\end{array}$ \\
\hline Organizational climate(OC) & 1 & & & \\
\hline Commitment(C) & 0.56 & 1 & & \\
\hline Job Involvement (N) & 0.45 & 0.77 & 1 & \\
\hline organizational citizenship behavior (OCB) & 0.68 & 0.60 & 0.56 & 1 \\
\hline
\end{tabular}

\section{The Structural Model Test}

In this study, confirmatory factor analysis for path analysis and the measurements test was used to confirm the structural model for the study.

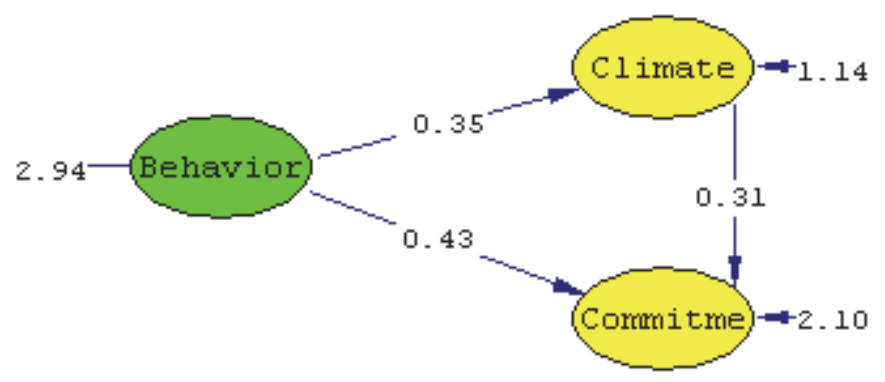

Figure 2. Structural model of commitment, organizational climate and organizational citizenship behavior in standard mode 


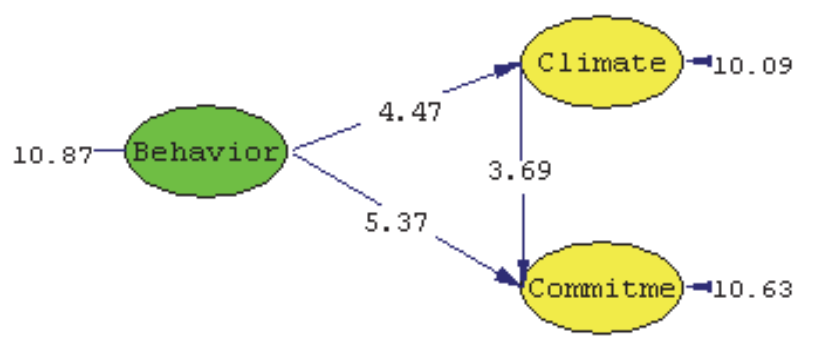

Figure 3: Structural model of commitment, organizational climate and organizational citizenship behavior in a significance

Table 4. Results of the review of goodness of fit

\begin{tabular}{|c|c|c|c|c|c|}
\hline AGFI & GFI & RMSEA & P-VALUE & DF & CHI--SQUARE \\
\hline 0.90 & 0.92 & 0.064 & 0.000 & 346 & 508.62 \\
\hline
\end{tabular}

Results of goodness of fit indices of the structural model in the table below indicate the model is fit. Because the amount less than 0.08> RMSEA indicate a good fit of the structural model. The values of CFI, GFI, AGFI, NFI, NNFI are all higher than 0.9 .

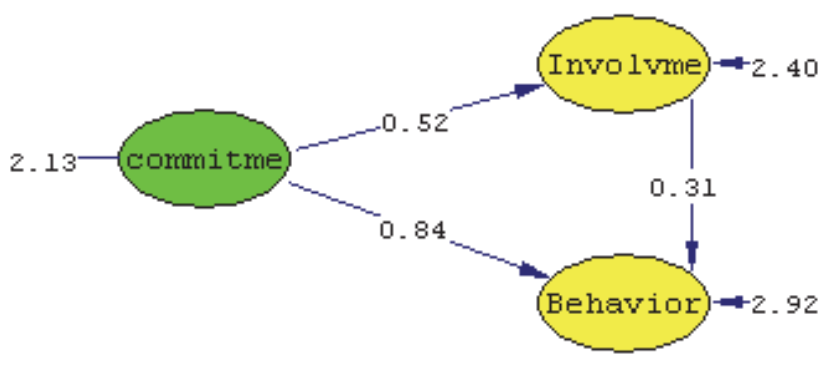

Figure 4: Structural model of commitment, involvement and organizational citizenship behavior in standard mode

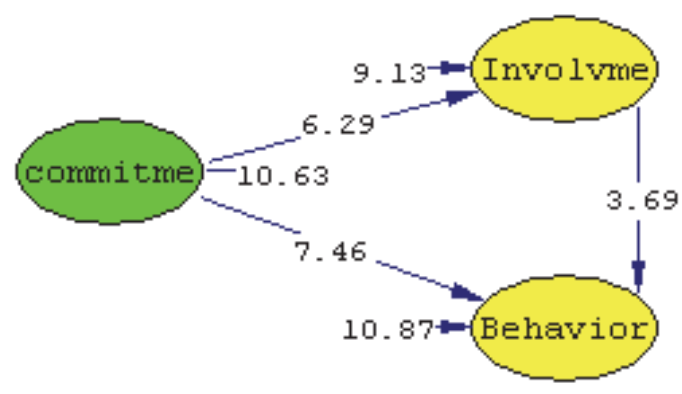

Figure 5. Structural model of commitment, involvement and organizational citizenship behavior in significance

Table 5. Results of the review of goodness of fit

\begin{tabular}{|c|c|c|c|c|c|}
\hline AGFI & GFI & RMSEA & P-VALUE & DF & CHI--SQUARE \\
\hline 0.90 & 0.91 & 0.075 & 0.000 & 402 & 709.26 \\
\hline
\end{tabular}

Results of goodness of fit indices of the structural model in the table below indicate the model is fit. Because the amount 
less than $0.08>$ RMSEA indicate acceptable fitness of the structural model. The values of CFI, GFI, AGFI, NFI, NNFI are all higher than 0.9 .

Table 6. The results of significance coefficients and direct relationship

\begin{tabular}{|l|c|c|c|}
\hline path & Abbr & t-value & $\beta$ \\
\hline Organizational climate ----Organizational commitment & OC---C & 3.69 & 0.31 \\
\hline Organizational citizenship behavior ---- Organizational climate & OCB --- OC & 4.47 & 0.43 \\
\hline Organizational citizenship behavior ---- Organizational commitment & OCB --- C & 5.37 & 0.35 \\
\hline Organizational commitment ---- Job involvement & C --- N & 6.29 & 0.52 \\
\hline Job involvement ---- Organizational citizenship behavior & N --- OCB & 3.69 & 0.31 \\
\hline Organizational commitment ---- Organizational citizenship behavior & C --- OCB & 7.46 & 0.84 \\
\hline
\end{tabular}

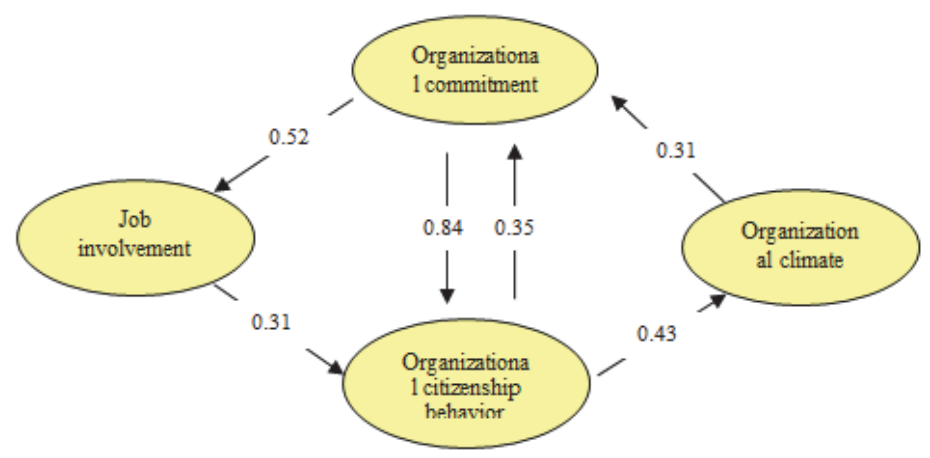

Figure 6. The model based on research findings

\section{Research Results}

\subsection{The first hypothesis}

As shown in Table 3 and Figure 2 the correlation coefficient and standardized path coefficient between organizational climate and organizational commitment are 0.56 and is 0.31 respectively that is statistically significant at the $95 \%$ level. It means in the office where there is a good organizational climate in which there is high level of organizational commitment so the research hypothesis based on the relationship between organizational climate and job commitment is confirmed.

\subsection{The second hypothesis}

As shown in Table 3 and Figure 2 the correlation coefficient and standardized path coefficient between job involvement and organizational commitment are 0.77 and is 0.52 respectively. So the results show that the relationship between organizational climate and job involvement is statistically significant at the $95 \%$ level.

\subsection{The third hypothesis}

As shown in Table 3 and Figure 4 the correlation coefficient and standardized path coefficient between job involvement and organizational citizenship behavior is 0.31 and 0.56 respectively and it is statistically significant at the $95 \%$ level. It means in the office where the job involvement is in good standing the organizational citizenship behavior of employees will occur more. So the researcher's hypothesis based on the relationship between job involvement and organizational citizenship behavior is confirmed. 


\subsection{The forth hypothesis}

As shown in Table 3 and Figure 2 the correlation coefficient and standardized path coefficient between organizational citizenship behavior and organizational climate are 0.35 and 0.68 respectively. So the results show that the relationship between organizational citizenship behavior and organizational climate is statistically significant at the $95 \%$ level.

\subsection{The fifth hypothesis}

As shown in Table 3 the correlation coefficient between organizational climate and job involvement is 0.45 . So the results show that the relationship between job involvement and organizational climate is statistically significant at the $95 \%$ level.

\section{Suggestions}

1- Due to the impact of organizational climate on employee engagement commitment it should be noted that employees' intimacy, interest, thoughtfulness, influence the dynamics and the production emphasis should be strengthen and the spacing of harassment by managers to take action should be improved.

2- According to the second hypothesis regarding the impact of employees' commitment on their job involvement it is emphasized to strengthen affective, continuous and normative commitment in Khuzestan Gas Company.

3- It is suggested to Company executives that job involvement questionnaire items that have positive aspects should be strengthen and try to improve inventory items with negative aspects because they have been affective according to the results of job involvement on organizational citizenship behavior.

4- According to confirm the relationship between organizational citizenship behavior and organizational climate it is suggested that managers to strengthen the social mores of organizational citizenship behavior, altruism, consciousness, generosity and courtesy in their efforts.

\section{References}

Abbasi, D. (1998). Factors affecting job commitment in faculty of Zanjan University, Master's thesis, Tarbiat Modarres University, Tehran. Alagheband, A. (2004). Theoretical Foundations and Principles of Educational Management. Ravan publication.

Appelbaum, S. et al., (2004). Organizational Citizenship Behavior: a case study of culture, leadership and trust", Management decision, Vol. 42, No. 1, p. 13-40.

Arnold, K. A. (2005). An Anachronistic approach to leadership theory: the case for inclusiveness. Honolulu, Hawaii, (august 5-1).

Bakker, A. B., and Demerouti, E. (2008). Toward a model of work engagement, career development international. 13 (3), 209-223.

Gonzalez, j and grazzo, t. (2006). Structural relationships between organizational service orientation, contact employee job satisfaction and citizenship behavior. International journal of service industry management, vol 17, no.1, pp: 23-50.

Mahdad, A. (2008). Industrial and Organizational Psychology, Tehran: the forest publication.

Meyer, J.P., Allen, N.J. (1991). A three-component conceptualization of organizational commitment, Human Resource management Review, 1:61-98.

Miller, K. (2003). Values, attitudes and job satisfaction, In Robbins, S. P., Odendaal A., \& Roodt, G. (eds), Organizational behavior: global and southern African perspectives. Cape Town: Pearson education South Africa.

Mir kamaly, S.M. (2001). Human relations in school, Yastaroon.

Mir Mohammadi, S.M. (2012). Original leadership and Job Involvement: Trust as a mediator variable, Journal of Public Administration Perspective, No. 12, pp 15-34.

Owens, R.G. (1986). Organizational behavior in education, Englewood cliffs, Newjersey, prentice hall, Inc third edition.

Podsakoff, P. M., Mackenzie, S. B., Paine J. B. and Bachrach, D.G., (2000). Organizational Citizenship Behavior: A critical review of the theorical and empirical literature and suggestions for future research". Journal of Management, 26, №. 3, p. 513-563.

Robbins, S. (2010). Organizational Behavior, translated by Ali Parsaeian and sayyed Mohammad Arabi, Tehran, Cultural Research Bureau.

Roux, S. (2010). The relationship between authentic leadership, optimism, self-efficacy and work engagement: an exploratory study. (Master dissertation) Stellenbosch University.

Senobari M. (2008). Organizational citizenship behavior (concepts, definitions, dimensions and factors affecting it), Journal of Police Human Development. No 16. pp 79-99.

Soleimani, N, Haghiri, A. (2011). Evaluation of managers moralizing with organizational commitment and job involvement of employees in Semnan city departments of education, Journal of Education, No. 107, pp 69-90.

Zare Bahram Abadi M, Darre I, Azhdari, G. (2010). The relationship between job involvement, responsibility and emotional analysis with job satisfaction, Journal of Counseling and Psychotherapy. No. 4. pp 5-24. 


\section{Appendix}

Structural model of commitment, organizational climate and organizational citizenship behavior in standard mode

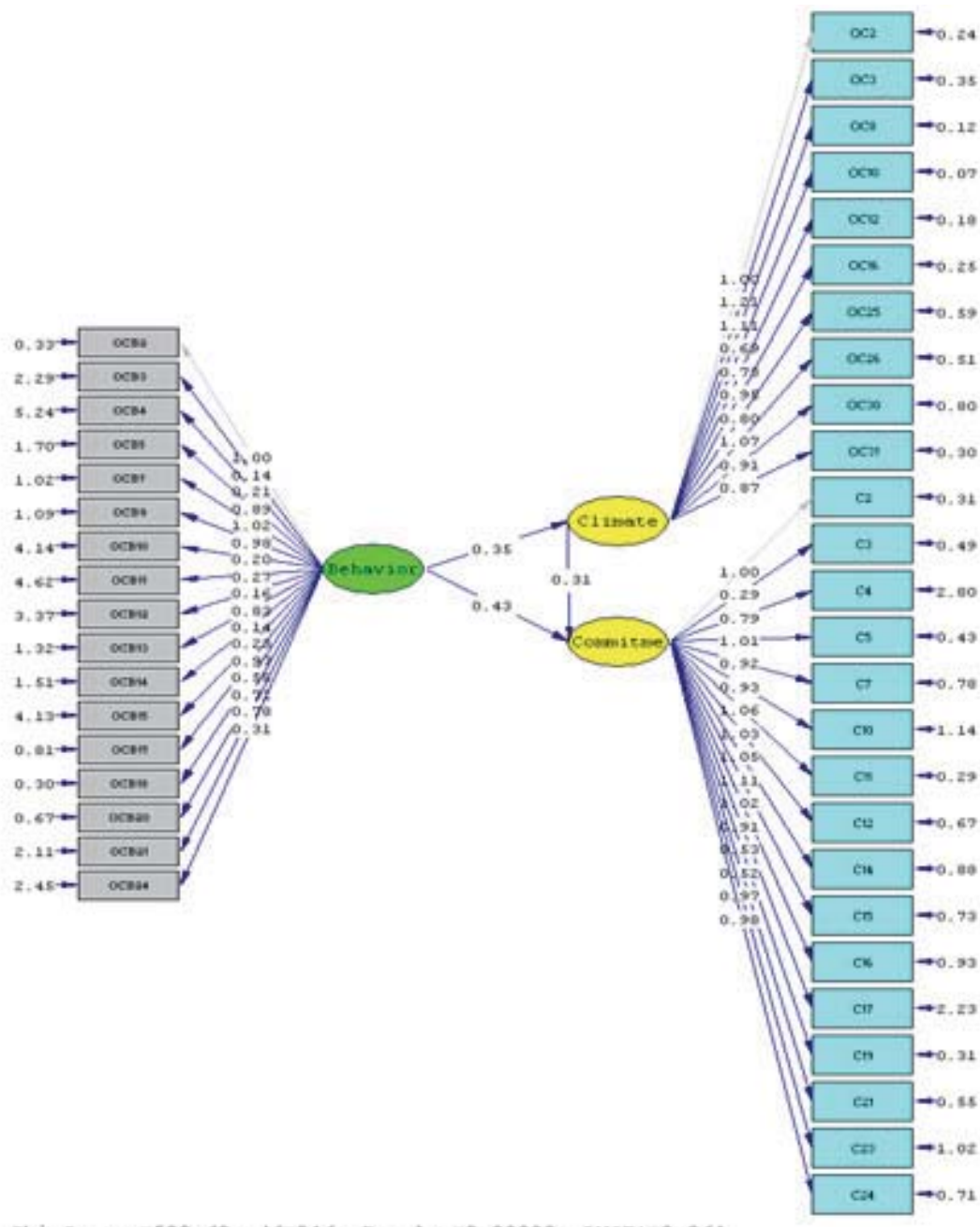

Chi-aquarem508,62, dt=346, E-valuem0.00000, hM8EA=0.064

Structural model of commitment, organizational climate and organizational citizenship behavior in significance 


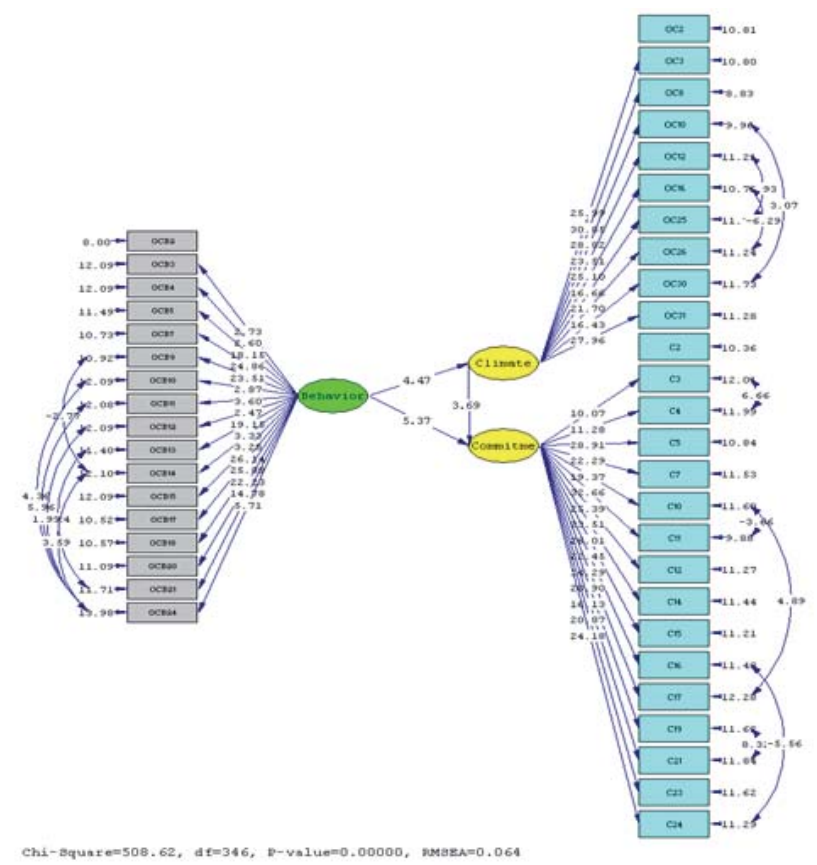

Structural model of commitment, involvement and organizational citizenship behavior in standard mode

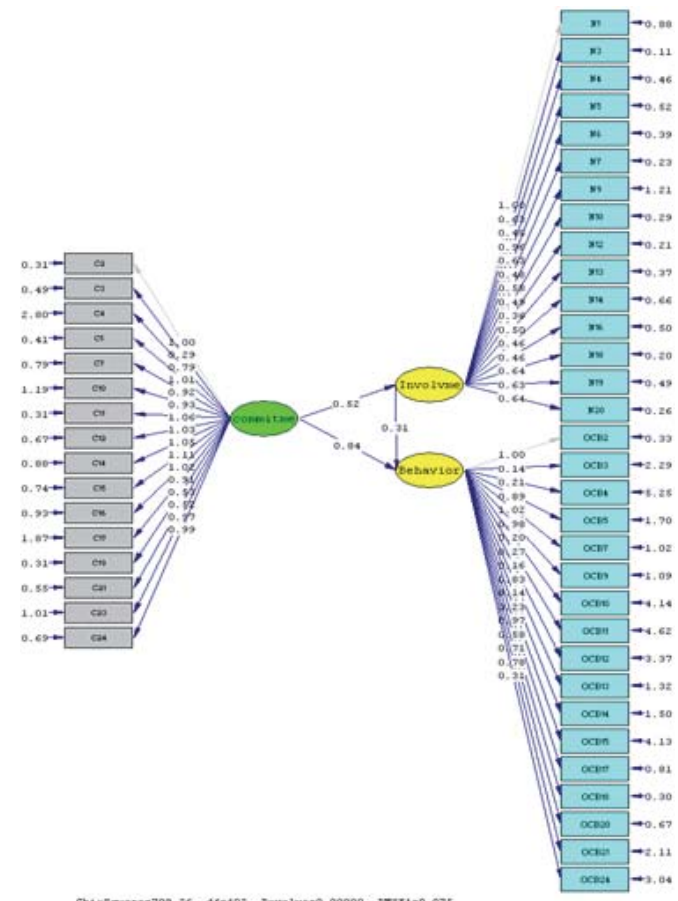




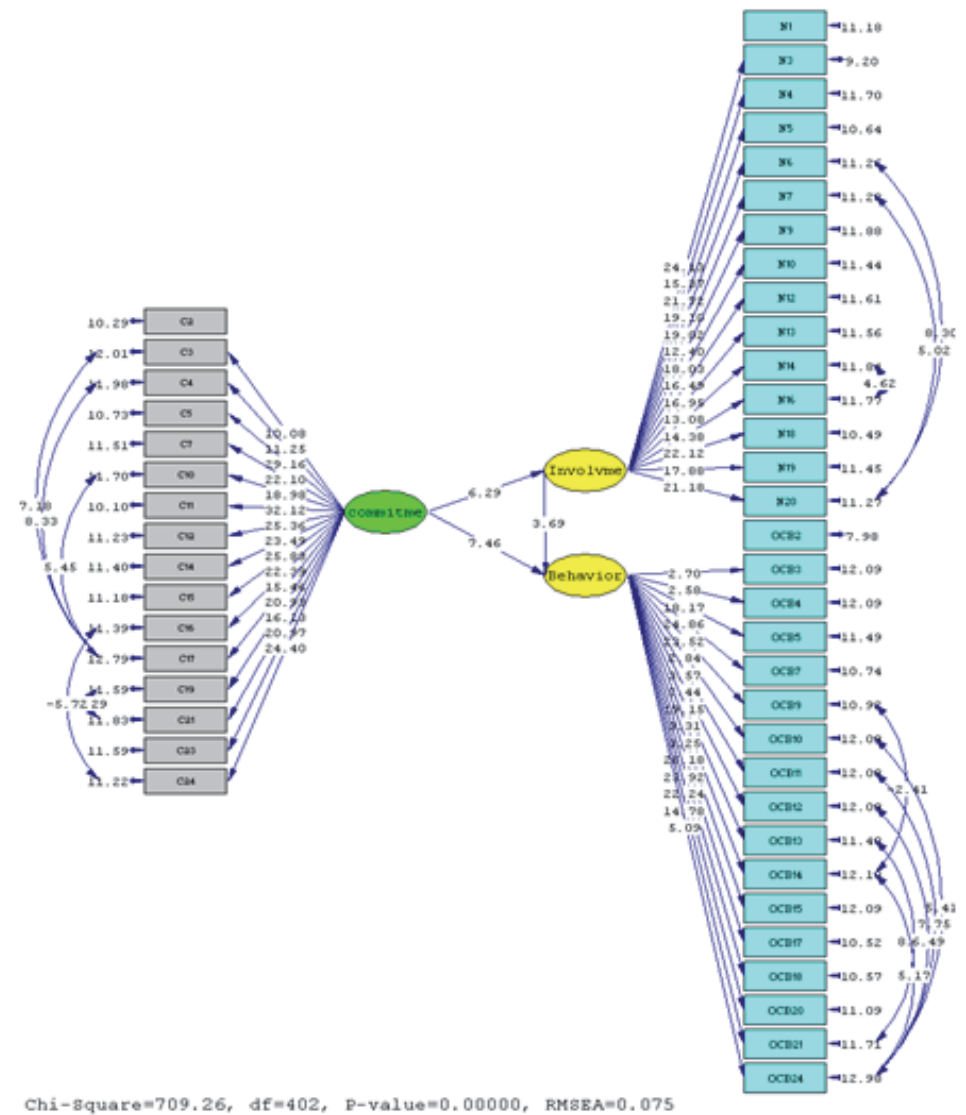

